\title{
Management Role of Al-Quds Open University in Leading Effective Distance Learning Programs: An Evaluation of QOU Experience in Blended Learning
}

\author{
Fathallah Ghanem \\ Majid Hamayil \\ Al-Quds Open University, Palestine
}

\begin{abstract}
Al Quds Open University has actually employed blended learning since 2007; it is becoming the basis for much of today's academic teaching. Therefore, this paper aimed at figuring out the extent that QOU managed distance learning programs effectively. The study reported here focused on the following factors: Vision and plans, quality assurance, curriculum, stafftraining/support, and student-training/support. Data were collected through a questionnaire administered online to the QOU instructors who were involved in blended learning teaching experience. Researchers claimed that QOU administration has applied the above mentioned factors effectively and efficiently in planning distance learning courses. It was obvious that QOU, focusing mainly high quality, has paid high attention to blended learning courses and invested in its training staff in order to achieve excellence in teaching and learning. However, the participants believed that the courses concerning the development of instructor skills and competencies were not sufficient enough and there was a clear need to revise the quality and quantity of such courses.
\end{abstract}

Keywords: Blended learning; Distance learning; Online learning; Open learning

\section{Introduction}

The administration and delivery of higher education in Palestine are mired with challenges, foremost the associated issues of mobility, security, and difficult socio-economic conditions. Despite this harsh environment, universities and colleges have continued to operate, for the most part, delivering a range of undergraduate and graduate programs all over Palestine. Unique to the Palestinian system is the large number of learners studying within an open university. Currently, over $40 \%$ of the undergraduate students in the West Bank, Gaza Strip, and East Jerusalem are studying at Al-Quds Open University (QOU). QOU is considered as the only institution in Palestinian Higher Education System that provides distance education courses and programs. Now it is serving 65,000 students and for the majority of these constituents provides their sole opportunity of higher education (Matheos, Rogoza, \& Hamayil, 2009). 
A comprehensive evaluation of QOU, funded by the World Bank and the European Union, resulted in a series of recommendations, paramount being the development of the scholarship of teaching within distance, open, and online environments.

QOU was positioned to respond to the recommendations. The use of technology as well as the availability of an infrastructure in QOU made it possible to consider the reconstruction of distance learning to integrate online learning into curriculum design. In 2008, QOU initiated a course redesign projects, aiming at moving from a correspondence model to a blended learning environment. This role clarified both challenges and opportunities (Matheos, MacDonald, McLean, Luterbach, Baidoun, \& Nakashhian, 2007).

Leadership is necessary to bring cohesion to the distance education arena within higher education. Drucker (1998) maintained that in the later part of the last century, technology resulted in a transformation of the social structure. As he saw the "rise and fall of the blue-collar worker" (p. 539), the rise of the industrial worker gave way to the rise of the knowledge worker, a term unknown prior to 1959 (p. 542). These societal and cultural changes meant that leaders were challenged to rethink how they encouraged management, workers, and organizations. If as Drucker (1998, p. 551) claimed, "Knowledge has become the key resource", ways need to be found to develop and share knowledge. This is the fundamental challenge for higher education transformational leaders.

A transformation is taking place in higher education regarding technology, the Internet, and education. This paper investigates some of the leadership aspects of transformation, and may provide useful guidelines for other institutions that are at a similar stage in transforming their distance education programs.

\section{Background}

\section{Establishment of the University}

QOU went through three stages during its establishment: Planning, preparation of curricula, and its actual functioning in Palestine.

First Stage (Planning): The idea of the establishment of the University started in 1975 based on the needs of the Palestinians for higher education, and taking into consideration their demographical, social, and economical situations under the Israeli occupation. Upon the request of the Palestinian Liberation Organization, UNESCO conducted a feasibility study for the University project, and in 1980 UNESCO General Conference approved it. The Palestinian National Council approved the plan in 1981; however, because of unfavorable circumstances, the execution of the project was delayed until 1985.

Second Stage (Preparation of Curricula): This stage started by the end of 1985 by opening a temporary office in Amman with the consent of the Jordanian Ministry of Foreign Affairs. During the period from 1985 to 1991, committees of specialists were preparing academic programs and 
specializations, study plans, and the production of educational materials such as textbooks and supportive educational media, mainly audio-visual aids.

Third Stage (Execution and Implementation): This stage started in 1991 when the University undertook its educational services with its headquarters in Jerusalem. It spread its educational regions and study centers in major Palestinian cities that included few hundred learners. The number of students has been increasing since then that it has reached 50,000 in 2005. The first group of graduates was in 1997 . This stage was especially hard because it coincided with the first Palestinian Intifada (Uprising) that started in 1987 and continued for six years. The University suffered a lot because of the destructive economic consequences of the First Gulf War on the Palestinian population and the Arab Nation. Despite the unavoidable bad circumstances and hardships, the University continues to function because of the faithfulness of its administration to the principles and mission of the University. The ideas of steadfastness and struggle have been taken from the historical leadership of the people of Palestine. Every Palestinian is now sure that the University, with a student population of 65,000 as of 2010 , remains a source of knowledge to every Palestinian home.

QOU is an undergraduate institution offering five programs: Technology and Applied Sciences, Agriculture, Social and Family Development, Administrative and Economic Sciences, and Education. Soon it will start offering three master programs in Education, Social and Family Development, and Public Administration.

In 2006-2007, the World Bank and European Union funded a Comprehensive Evaluation of QOU as a component of a larger tertiary education initiative in Palestine. QOU responded to the proposed recommendations with the establishment of the Open and Distance Learning Center (ODLC) with a mission to develop and enhance excellence in distance teaching and learning across the institution. A director, who holds a PhD degree in education with undergraduate and graduate degrees in engineering, was appointed as a direct report to the Vice-President for Academic Affairs. The establishment of the ODLC provided the forum to revisit teaching and learning at QOU.

Blended learning at the university starts moving in the following tracks: Academic Portal, Avicenna Virtual Campus Project, Production of Multimedia Contents, and Open Distance Learning Center. With face-to-face meeting for the whole courses, instructors conduct their classes and meet their students in the classroom. Using the portal and Avicenna site and others serve as help tools for learners with no grading system assigned for such tools. However, starting 2007 until now QOU implemented blended learning as a mixture of online and face-to-face learning using a variety of learning resources and communications options available to students and instructors. In other words, blended learning mixes e-learning with traditional types of learning. By applying and practicing blended learning, the conveniences of online courses are gained without loss of face-to-face communication. Implementing both methods can create a learning environment which is richer than either a traditional face-to-face environment or a fully online one. Instructors and students meet $50 \%$ face-to-face of the total lectures, while instructors have to conduct the other (50\%) as virtual classes using illuminate live. Additionally, students have to access their courses through the Moodle that QOU offers. Students there have to do certain 
activities such as discussing forums, answering activities, taking online exams, and using blogs, wikis, etc. These activities have $25 \%$ of grading system. Also, students have to take midterm and final exams on the campus.

However, to some extent students could not choose their own learning style. QOU has been applying blended learning because they perceive that students may not be able to cope with a fully online course. QOU tries to help its students have access and use technology well. QOU wishes to offer extra support to weaker students. Other institutions used blended learning in order to reduce the face-to-face component of the teaching so that part-time students and those who have family responsibilities are able to get better access to learning. However, researchers and practitioners noted that technology-enhanced learning alone was not enough, arguing that people needed experiential learning for the mastery and retention of knowledge and skills achieved through the blending of technology and face-to-face interaction (Collis \& Moonen, 2001; Singh, 2003).

Blended learning means different things to different people. There is a growing literature that associates blended learning with flexible delivery of instruction (Collis \& Moonen, 2001). Others regard blended learning as an important building block of the new schoolhouse, which offers students both flexibility and convenience, important characteristics for working adults who decide to pursue their degree-driven study (Rovai \& Jordan, 2004). Collis and Moonen (2001) argue that blended learning is a hybrid of traditional face-to-face and online learning so that instruction occurs both in the classroom and online, and where the online component becomes a natural extension of traditional classroom learning. Hybrid is yet another term found in the literature. University of Wisconsin defines a hybrid course as one that combines face to face and online learning.

Blended learning has also been treated as an alternative strategy to enhance knowledge transfer and performance support in order to attain better business results (Collis and Moonen, 2001; Driscoll, 2002; Marsh, 2002; Valiathan, 2002). There are several research activities on blended learning in the corporate sector. For example, Singh and Reed (2001) explore the nature of blended learning and the incorporation of blended learning approaches to support business success. Bersin (2003) focuses on the selection criteria for the use of media in blended approaches in a range of contexts. Julian and Boone (2003) show how blended learning solutions and robust learning services can help companies to develop their workforce and manage their intellectual capital. Marsh (2002) provides approaches for designing effective blended learning for the Brandon Hall Company. Further, Driscoll (2002) presents the notion of blended learning as a strategy for gradual movement from a traditional course delivery into Web-based platform within IBM. Valiathan (2002) identifies three categories of blended learning for training and performance: Skill-driven learning activities focusing on teaching a specific set of skills, learning activities geared toward change in attitudes, and blending performance support tools with knowledge management resources and mentoring to develop workplace competencies.

In academia, blending lectures with seminars, workshops, bulletin board discussions, and offcampus and on-campus learning activities had existed prior to the construct of blended learning within the corporate world. Despite the preponderance of blended learning practices within 
academia, blended learning was not initially identified as a specific issue in the academy. More recently, however, "blending" emerged as a powerful force for campus-based traditional universities to improve teaching and learning. The permeation of blended learning ideas into academia is accompanied by several research activities. Collis and Moonen (2001) has examined the notion of blended learning in academia, its current status and future directions. Troha (2002) has investigated a process-oriented blended learning design model, which presumes the notion of blended learning is increasingly gaining popularity as an effective pedagogical approach that integrates classroom and technology-enhanced learning

\section{Academic Portal}

The aim of the portal is to make learning student-centered, increase productivity, and make better, use of human effort and energy. Its usage would be of greater benefit to students and staff alike, but has to cope with growing numbers of users and current network performance problems. It is planned to emphasize first on the content, and then focus on institutional processes, services, technology applications, and process integration. The last phase is to integrate data, voice, and video on a variety of platforms (such as handheld computers), perhaps over wireless networks. Main functions of the Portal currently include: Student Information System, News and Bulletin Boards, Course Learning Management, Online Admission and Registration, e-Learning Modules, and Other Activities (Hodali \& Amro, 2004).

\section{Avicenna Virtual Campus Project}

Avicenna Virtual Campus is an ambitious project that aims at creating new community of universities sharing best practices and pedagogical innovation through a network of E-learning centers across the Mediterranean. It involves 15 countries including Palestine which is represented by Al-Quds Open University. To realize one of its important objectives, E-Learning has become a key part of QOU development strategy. The project is dedicated to accelerating the adoption and best use of ICT-assisted Open Distance Learning (ODL) in 11 Mediterranean non-EU Member States. Demand for ODL in the target universities and societies already exist. The project aims at establishing adequate local infrastructures and to transfer best practice as well as professional know-how within target universities. The project is named after Ibn Sina (981-1037) the most famous philosopher of his time (http://pleiad.unesco.org/portal/index.html?articl=0).

\section{Production of Multimedia Contents}

The implementation of the project started in May 2000 via the German Agency for Technical Cooperation (GTZ), where the university provided the suitable space and a working team including executive experts and assistants to carry out the project. GTZ provided the equivalent counterparts to follow up and carry out essential training. It also contracted the center with a German media expert to train and advise the staff on the production of educational multimedia. The center embraces an Audio/Video Studio, a Full Sound System Studio, PC-based Video Editing 
Units, and a Central Graphics Workstation. Their main function is the production of high quality audio-video educational material that assists the learner in his/her pursuit of higher education based on the Distance Education and Open Learning Systems. The production process utilizes the latest and state-of-the-art technologies, where the EMPC provides the educational media on VHS and DAT tapes, as well as CDs, VCDs and DVDs. The Center conducts training workshops and seminars for Al-Quds Open University's academic advisors and EMPC's employees, thus implementing its mission in continuously developing and advancing the technical know-how of crew and staff.

\section{Open Distance Learning Center (ODLC)}

Open and Distance Learning Center (ODLC) is one of the university's educational-technical centers, which was established in March 2008 to achieve several goals including raising staff competencies in distance learning and eLearning in line with ongoing development in the educational/learning process, enhancing education with ICT, dissemination of open and distance education philosophy as well as blended learning, development of eLearning environments in collaboration with involved departments/centers, and the application of educational best practices according to the quality standards of open and distance education as well as effective blended learning (Hamayil, 2010).

\section{eLearning Systems and Technologies}

1. Moodle Learning Management System (LMS) includes three subsystems:
a. eTraining LMS
b. Students LMS (eActivities)
c. Students LMS (eAssignments)

2. OLAT Content Management System (CMS)

3. ELLUMINATE LIVE Virtual Class Technology

4. Video Streaming Technology

\section{ODLC Achievements}

Since its establishment in March 2008, ODLC achieved most of its objectives in full cooperation with other QOU departments and centers. These are:

1. Development of a number of training programs and courses which targeted more than 1602 academic and administrative staff and more than 62 students within the studentssupport program (1500 recorded eTraining hours).

2. Implementation of the Capacity Building (Project-Phase I), and starting Phase II, which aims to strengthen the e-learning infrastructure, in addition to holding training workshops in self-assessment tools for open and distance learning. This project is 
funded by the World Bank and the European Union under the auspices of the Ministry of Education and Higher Education.

3. Development and teaching of 128 eCourses with blended learning model during the last four semesters, which targeted thousands of students. For instance, the number of enrolled students in the blended courses in the second semester (1092) of the academic year 2009/2010 has exceeded 35,000.

4. Proposing the "Students Support in e-learning environment" project in collaboration with QOU's departments and centers for fund raising.

5. Establishing and maintaining a free educational network for academic staff in collaboration with the directors of academic programs (http://qoupal.ning.com).

6. Designing a database for self-assessment tools for academic and administrative staff through the Capacity Building project, and hosting it on QOU's academic portal on the link: http://odlc.qou.edu. It involves some questionnaires that should be answered by the target groups, and statistically analyzed to extract some recommendations. These questionnaires, literature, and reference points are used by QOU to announce eLearning educational regions, as it is the case in Hebron, Ramallah, and Rafah regions.

7. Preparation of professional diploma program specialized in distance learning and eLearning in higher education institutions in cooperation with the related departments and centers at QOU.

8. Providing guidance and training materials in the plan to disseminate the culture of blended learning eLearning technologies at QOU.

9. Employing a team of specialists to provide educational and technical support for the concerned students and instructors at QOU.

10.Conducting variety of applied research studies in blended learning, and access to variety of global electronic journals and books, all specialized in open and distance learning, which were funded by the World Bank and the European Union in the Capacity Building project.

The first challenge for the QOU redesign project was to define and develop a model for blended learning appropriate for an open and distance institution that had utilized print-based study with optional face-to-face tutorials for over ten years. For the purpose of this discussion, blended learning is conceptualized as a learning environment where multimodal approaches to instruction utilize face-to-face and online technologies. The benefit of using a variety of modalities is that it appeals to different learning styles with the online components allowing for ease of access. Building on the definition presented by (Garrison, 2003; Garrison and Vaughan, 2007), blended learning at QOU was defined as the thoughtful fusion of oral and written communication, as well as interaction and engagement with multiple resources such as audio, video, graphics, 
simulations, and immersive environments. Critical to this model is the concept that academic program and course goals and objectives drive the pedagogical approaches and technologies used (Matheos, Rogoza, \& Hamayil, 2009).

Bates (2000) referred to Daryl Le Grew, an international distance education advocate from Deakin University, Australia, who described "a paradigm shift" that is currently taking place in higher education. Examples included the transition from an industrial society to an information society, from a once only education to lifelong education. Green (1999) further summarized the issue as the following: "...We are witnessing a significant evolutionary event in American higher education. This event is the emergence of distance education and distributed learning" (p. 13). Informed, visionary leadership is necessary to match this change.

\section{Definition of Terms}

Blended Learning at $Q O U$ is a mixture of online and face-to-face learning environment using a variety of learning resources and communication options that are available both for students and instructors.

Video Streaming at QOU is a mixture of online video streaming (30\%) where students can attend classes online, and/or listen to the recorded lectures in any time they choose, while the rest (70\%) is for face-to-face lectures in addition of using the QOU academic portal. In the grading system of such courses, students have to take two online assignments that have a $10 \%$ of grading; while midterm and final exams cover $90 \%$ since they are tested on the campus.

MOODLE Learning Management System (LMS): Moodle is a Course Management System (CMS). It is also known as a Learning Management System (LMS) or a Virtual Learning Environment (VLE). It is a free web application that educators can use to create online learning courses which require both instructors and students to have adequate training to use it appropriately. There are two different learning environments which namely are:

1. eActivities environment: Students have to attend $50 \%$ face-to-face meetings and another (50\%) which covers both virtual classes and participating in the moodle activities as well, i.e.: forums, blogs, wikis. eActivities have $25 \%$ of the total grade, while midterm and final exams cover $(75 \%)$ of grading system since they are tested in the campus.

2. eAssignments environment: It refers to $10 \%$ of two online assignments, $90 \%$ campus exams of courses with $50 \%$ face-to-face meetings, and $50 \%$ assigned for attending virtual classes.

In addition to that QOU offers eTraining sessions designed by specialist trainers both for instructors and students to qualify them to be able to use LMS moodle and virtual classes for blended courses. 


\section{Objectives of the Study}

The study seeks answers to the following questions: 1) To what extent does QOU management devote in providing instructors with the Vision and Plans of e-learning?; 2) To what extent do QOU instructors believe they have acquired the necessary cultural and literary knowledge that makes them aware of teaching blended courses in compliance with quality assurance?; 3) To what extent QOU instructors familiar with the curriculum of the subjects they are teaching?; and 4) To what extent does QOU provide instructors and students with sufficient training for coursework in blended courses?; 5) Are there any significant differences in the mean of respondents' perception in QOU management role in leading effective distance learning programs when respondents are grouped according to their personal profile?; 6) What are the obstacles instructors face while teaching blended learning course, and also the solution to such obstacles as perceived by them?

\section{Significance of the Study}

This study is based on the concept of Al-Quds Open University management role in emphasizing blended learning courses that have been in operation since 2008. Therefore, this study will be very valuable to the administrators and faculty members of the QOU. Findings will provide direction to further usefulness of e-learning implemented by QOU. The study is considered significant also from two additional perspectives. First, it focuses on the specialist competencies namely proficiency of instructors in blended learning. Second, the study is one of the few studies in the region in general and in Palestine in particular that addresses blended learning outcomes in relation to the management aspects, which are very essential in places where e-learning is a new tool (such as QOU). It is also important to the respondents, professionals, and to knowledge seekers who look for related materials; this study will be useful and/or serve as a body of information for e-learning in other academic institutions.

\section{Scope and Limitation}

This study is limited in the following aspects:

Topic: The study is limited to examine QOU management role in leading effective distance learning programs in blended learning via QOU e-activities moodle in five dimensions: Vision and Plans, Quality Assurance, Curriculum, Staff-Training and Support, Student-Training and Supports.

People: This study is limited to 58 instructors teaching blended courses in the 2nd Semester 2010 at Al -Quds Open University via the moodle http://eactivities.qou.edu

Place: This study is limited to 22 educational regions of Al-Quds Open University scattered all over Palestine, including Gaza Strip and Jerusalem.

Time: This study is limited to the 2nd Semester 2010 at Al -Quds Open University. 


\section{Methods of Research}

This study utilized the descriptive approach of research to deal with the data regarding QOU management role in blended learning. Questionnaires and interviews were employed to identify prevailing conditions that answered the questions of the study.

\section{Participants}

58 instructors were selected based on their capability of teaching blended learning courses all over Palestine including Gaza Strip and Jerusalem. The researchers selected this particular group since they had already been trained to teach blended learning courses in the academic year $2009 / 2010$.

Table 1. Participants' Profile

\begin{tabular}{|c|c|c|c|c|c|}
\hline Gender & Frequency & Percentage & Status & Frequency & Percentage \\
\hline Male & 39 & 84.8 & Full-timer & 35 & 76.1 \\
\hline Female & 7 & 15.2 & Part-timer & 11 & 23.9 \\
\hline Total & 46 & 100.0 & Total & 46 & 100.0 \\
\hline Age & Frequency & Percentage & Computer skills & Frequency & Percentage \\
\hline Less than 30 yrs & 4 & 8.7 & Excellent & 25 & 54.3 \\
\hline $30-35$ yrs & 19 & 41.3 & Very good & 13 & 28.3 \\
\hline $36-40$ yrs & 17 & 37.0 & Good & 8 & 17.4 \\
\hline More than 40 yrs & 6 & 13.0 & Average & 0 & 0.0 \\
\hline Total & 46 & 100.0 & Poor & 0 & 0.0 \\
\hline Experience & Frequency & Percentage & Total & 46 & 100.0 \\
\hline $\begin{array}{l}\text { One to two } \\
\text { semesters }\end{array}$ & 25 & 54.4 & $\begin{array}{c}\text { Availability of } \\
\text { Internet Service }\end{array}$ & Frequency & Percentage \\
\hline Three semesters & 7 & 15.2 & DSL - home & 38 & 50.0 \\
\hline Four semesters & 10 & 21.7 & DSL - office & 4 & 41.3 \\
\hline Total & 46 & 100.0 & Dialup & 2 & 4.3 \\
\hline Program & Frequency & Percentage & $\begin{array}{c}\text { Don't have, I use } \\
\text { QOU Labs }\end{array}$ & 2 & 0.0 \\
\hline Management & 14 & 23.9 & Total & 46 & 100.0 \\
\hline Computer & 11 & 21.7 & Qualification & Frequency & Percentage \\
\hline Social Science & 12 & 54.3 & Masters & 11 & 23.9 \\
\hline Education & 9 & 0.20 & Doctoral & 35 & 76.1 \\
\hline Total & 46 & 100,0 & Total & 46 & 100.0 \\
\hline
\end{tabular}

Participants' profile appears to be male-dominated as indicated by $84.8 \%$. This situation is typical in the higher education system of Palestine and also consistent with the tradition of the Palestinian practice for preferring males to pursue their higher education. On the other hand, as 
the Bureau of Statistics of Palestine presented in its yearly publications, more than fifty percent of females end up with high school. This supports the fact that Palestinian women are less inclined to pursue their higher education as they end up with marriage at an early age. The offered justification is that women in the Palestinian environment are reluctant to get higher degrees or post-graduate degrees as they believe that this is a male domain. Thus, there was a clear evidence that more than three fourth of the respondents or $78.3 \%$ are classified in the youth category which is the productive age for those who started e-learning three years ago. Only two instructors started such an experience in the first semester of 2008. The number of instructors has been increasing since then. Most of them are full timers (76.1\%) as the table shows, who are aware of technology skills required for teaching blended learning courses. The majority of the participants holds doctoral degree and has DSL internet connection at home.

\section{Sampling Techniques}

This study took the total population of 58 instructors, and therefore no sample was selected. However, 5 instructors didn't participate in the study and 53 questionnaires were returned, of which (7) questionnaires were excluded because of some missing data. As a result, a total of 46 questionnaires were processed in analyzing data.

\section{Instrumentation}

Researchers constructed a questionnaire based on extensive reading in the related educational literature and interviewing key people in Al-Quds Open University, in addition to comprehensive meetings with QOU President Assistant for E-learning Affairs - Director of Open and Distance Learning Center (ODLC), and the pre-testing of the questionnaire. The questionnaire is divided into three parts. The first part required the respondents to provide their personal data as to (gender, age, experience in e-learning, status of instructors, computer skills, internet service). The second part consisted of questions regarding the degree of agreement on the role of QOU management in leading blended learning. This part had 49 items distributed over 5 dimensions as follows:

- QOU vision and plans and contains (8 items)

- QOU quality assurance and contains (10 items)

- QOU curriculum and contains (10 items)

- QOU staff-training and support and contains (10 items)

- QOU student-training and support and contains (11 items)

Part three was as an open question asking instructors about obstacles and solutions, requiring them to comment on the obstacles and solutions from the point of their experience in teaching blended courses. 
The Likert-type scale, as a part of the data gathering instrument, was designed to assess the participants' perceptions of their specialists' competencies. The researchers dedicated five choices of responses in the Likert-type scale: Strongly agree (5), Agree (4), Neutral (3), Disagree (2), Strongly disagree (1). The instrument yielded 0.915 reliability estimate using Guttmann splithalf correlation analysis and the accompanying Unequal length Spearman Brown Prophecy Correction Formula.

Table 2. Lower and Upper Limits of Scale Options

\begin{tabular}{|l|c|c|c|}
\hline Five Point Scale Qualitative Description & No. & Shortcuts & Quantitative Weighted Mean \\
\hline Strongly Agree & 5 & SA & $4.21-5.00$ \\
\hline Agree & 4 & A & $3.41-4.20$ \\
\hline Neutral & 3 & N & $2.61-3.40$ \\
\hline Disagree & 2 & D & $1.81-2.60$ \\
\hline Strongly Disagree & 1 & SD & Less than 1.81 \\
\hline
\end{tabular}

\section{Data Gathering}

To facilitate distribution and speedy collecting of the questionnaire, the researchers employed a high tech tool for gathering data. The questionnaire was loaded into QOU portal, which required instructors to download it, fill it out, and then upload it via the portal. No paper-and-pencil kind of questionnaire was used in this study. Besides the questionnaire, some additional data were gathered by the researchers through interviewing instructors in different areas and some key people of QOU.

\section{Statistical Treatment of Data}

Statistical techniques such as frequency distribution, percentage, mean, weighted mean, mean average, ranking, and one way analysis of variance were used in the analysis of data. For the hypothesis posed, the Kruskal Wallis Test was utilized. The Kruskal Wallis Test is a nonparametric test equivalent to one way analysis of variance (ANOVA). This was used to determine the differences of the respondents' perceptions on evaluating their agreement of QOU management role in blended learning, when the respondents were grouped according to: Gender, Age, Experience, Program Type, Tutor Status, Computer Skills, Type of Internet Connection, and Tutor Qualification.

\section{Findings}

\section{Question One}

To what extent does QOU management devote in providing instructors with the Vision and Plans of e-learning? 
The participant's acquisition of QOU vision and plans was measured by averaging the participants' responses. Means, numbers and standard deviations are reported in Table 3. ODLC plans which are incorporated into existing strategic planning documents obtained a mean value of $(M=4.17)$ or $83 \%$ which gains participants agreements on that element. Apparently, most of the instructors indicate that they have acquired the necessary information via QOU portal with regard to any latest decisions and resolutions about the improvement and design of the e-learning courses, and as a policy of keeping faculty and staff alert of such changes. As a result of that, faculty involved in teaching in blended learning mode, can refer to these updates in their practice, although they are not fully independent users skilled in this new environment.

This result seems to be in line with some research evidence (Bates, 2000; Kovel-Jarboe, 1997; Lape \& Hart, 1997). This perspective would also facilitate the instructors to deal with QOU vision and plan for blended learning courses. On the other side, a registered mean $(M=3.7)$ or $74 \%$ which gain respondents' agreements as ODLC involves faculty in determining the priorities, policies, and procedures for implementing electronic learning from the very beginning.

The researchers could draw a conclusion on this element that ODLC could not give instructors a full freedom in implementing the electronic learning curricula due to the minimum number of skilled and specialized instructors in this domain. However, Table 3 in general registered a mean average of ( $\mathrm{M}=3.92)$ which obtains respondents' agreement, as QOU discloses its vision and plans to instructors.

Table 3. Respondents' Perception - Vision and Plans ( $N=46)$

\begin{tabular}{|l|c|c|l|}
\hline $\begin{array}{l}\text { Section I: Vision and Plan- } \\
\text { In this e-activities blended learning courses; }\end{array}$ & Mean & Std.dev & INTE_VAL \\
\hline QOU vision is clear and understandable to me & 3.85 & .59507 & Agree \\
\hline $\begin{array}{l}\text { ODLC programs are implemented based on a vision that is } \\
\text { universally shared and where the goals are clearly stated }\end{array}$ & 3.91 & .28488 & Agree \\
\hline $\begin{array}{l}\text { ODLC plans are incorporated into existing strategic planning } \\
\text { documents and available to us via portal }\end{array}$ & 4.17 & .64306 & Agree \\
\hline $\begin{array}{l}\text { ODLC polices and procedures for blended learning are clear an } \\
\text { understood to me }\end{array}$ & 3.83 & .82474 & Agree \\
\hline $\begin{array}{l}\text { ODLC involves faculty in determining the priorities, policies, and } \\
\text { procedures for implementing electronic learning from the very } \\
\text { beginning. }\end{array}$ & 3.65 & .76645 & Agree \\
\hline $\begin{array}{l}\text { ODLC allow faculty to lead change for the academic quality of the } \\
\text { courses. }\end{array}$ & 3.83 & .87697 & Agree \\
\hline $\begin{array}{l}\text { ODLC care for the promotion and support of a culture of innovation } \\
\text { and continuous improvement }\end{array}$ & 3.96 & .75884 & Agree \\
\hline $\begin{array}{l}\text { ODLC provide me with the vocational guidance for the } \\
\text { management decisions mode of my subject }\end{array}$ & 4.15 & .75916 & Agree \\
\hline Mean average & 3.92 & & Agree \\
\hline
\end{tabular}




\section{Question Two}

To what extent QOU instructors believe they have acquired the necessary cultural and literary knowledge that makes them aware of teaching blended courses in compliance with quality assurance?

Table 4 shows that each element in the questionnaire with reference to quality assurance varies between obtaining information to acquiring quality assurance on the courses that the instructors teach, as ODLC provides instructors with the standard for designing blended courses which obtain a mean of ( $M=4.35)$ which is interpreted as strongly agree. This result indicates and proves a subconclusion in question one, as ODLC is keen on involving faculty from the beginning of making all resolutions about e-learning courses until the level of executing them to obtain high quality in teaching these courses. Another finding suggests that ODLC is also eager to provide its faculty necessary training to qualify them to teach in this mode, to ensure the quality of the designed courses and the performance of its practicing faculty, and to be evaluated by the quality and assurance department.

Although it is agreed by the respondents that ODLC criteria used for measuring the quality of blended courses that meets the standards of a good book obtained a mean of $(M=3.46)$, this can be explained by faculty's new experience in the novel activities used in the moodle, which they aren't accustomed to in traditional teaching. Subsequently, as not all of them are fully specialized in applying the new instructional strategies in their teaching, they might not be fully aware of the achievement of these activities to the intended learning outcomes of the e-course they teach. The table registered a mean average of $(M=3.89)$ which indicates $Q O U$ awareness to maintain from the beginning a high quality of its blended courses via its portal. This result was in line with some research evidence (Hall, 1995). Also, from the previous discussion, researchers conclude that QOU considers quality of education as a priority in its system of teaching.

Table 4. Respondents' Perception - Quality Assurance ( $N=46)$

\begin{tabular}{|l|c|l|l|}
\hline $\begin{array}{l}\text { Domain II: Quality Assurance } \\
\text { In this e-activities blended learning courses; }\end{array}$ & Mean & Std.dev & INTE_VAL \\
\hline ODLC provides me with the standard for designing blended courses & 4.35 & .76645 & S. Agree \\
\hline $\begin{array}{l}\text { ODLC Processes to take care for improvement of learning and } \\
\text { teaching processes. }\end{array}$ & 3.63 & .82620 & Agree \\
\hline The KPIs ODLC uses for measuring my blended course is clear to me & 3.70 & .59140 & Agree \\
\hline ODLC has a specialized team for measuring blended courses quality & 3.76 & .73590 & Agree \\
\hline $\begin{array}{l}\text { ODLC criteria used for measuring blended courses quality meet the } \\
\text { standards of a good book }\end{array}$ & 3.46 & .83550 & Agree \\
\hline $\begin{array}{l}\text { ODLC have standards for forum, activities, and quizzes used in } \\
\text { blended learning courses }\end{array}$ & 4.17 & .48554 & Agree \\
\hline $\begin{array}{l}\text { ODLC provides Client satisfaction to meet the needs and } \\
\text { expectations of students and academic supervisors }\end{array}$ & 4.17 & .87697 & Agree \\
\hline $\begin{array}{l}\text { ODLC has impact on the university's success by employing global key } \\
\text { performance indicators in blended courses. }\end{array}$ & 3.67 & .87062 & Agree \\
\hline ODLC has impact on the training of the staff members, where staff & 4.22 & .84098 & S. Agree \\
\hline
\end{tabular}




\begin{tabular}{|l|c|c|l|}
\hline courses evaluated by quality department. & & & \\
\hline $\begin{array}{l}\text { ODLC encourages students to react as they are asked to evaluate the } \\
\text { course after completing it }\end{array}$ & 3.80 & .98024 & Agree \\
\hline Mean average & $\mathbf{3 . 8 9}$ & & Agree \\
\hline
\end{tabular}

\section{Question Three}

To what extent QOU instructors are familiar with the curriculum of the subjects they are teaching?

Table 5 illustrated that the mean average of the respondents perceptions regarding the curriculum was the highest $(M=4.14)$ where they believed that giving high attention to understand the curriculum of the subject they teach give them more understanding. However, it was highly weighted as it was evident by the mean of $(M=4.46)$ where ODLC faculty have adapted their lectures to the advances provided by technology such as PowerPoint presentations and multimedia demonstrations through virtual classes for the importance and efficiency of using such multimedia in the effectiveness of delivering a successful virtual lecture. In addition, this will valuably be reflected in their students' motivation in learning in this new mode, and building a confidence in benefiting from their lectures as well as in the performance of their teacher. As a result, a noticeable augmentation in their attendance to their virtual lectures would definitely achieve QOU goal in attracting students to learn in this mode.

While it was the lowest mean to be registered $(M=3.93)$ in the clarity of content delivering of the different activities used in the moodle and the design of it is based on pedagogical base, this result was not in line with some research (Tichy \& Devanna, 1986, p. 4). Therefore, the researchers' conclusion in this element was that QOU tries to integrate several technological methods of teaching in the blended courses and are still in the process of training and enhancing instructors for efficiency and effectiveness to gain greater acceptance and usefulness of blended courses.

Table 5. Respondent's Perception - Curriculum ( $\mathrm{N}=46)$

\begin{tabular}{|l|c|c|l|}
\hline $\begin{array}{l}\text { Section III: Curriculum } \\
\text { In these e-activities blended learning course; }\end{array}$ & Mean & Std.dev & INTE_VAL \\
\hline The major plan of a course is based on pedagogic issues & 4.11 & .67423 & Agree \\
\hline $\begin{array}{l}\text { Blended courses are furnished with quizzes, exam, forums, } \\
\text { activities based on clear pedagogy. }\end{array}$ & 3.89 & .76676 & Agree \\
\hline $\begin{array}{l}\text { By letting faculty create their own classes as planned, delivery } \\
\text { styles improved }\end{array}$ & 4.24 & .60313 & S. Agree \\
\hline $\begin{array}{l}\text { ODLC faculty have adapted their lectures to the advances provided } \\
\text { by technology such as PowerPoint presentations and multimedia } \\
\text { demonstrations }\end{array}$ & 4.46 & .50361 & S. Agree \\
\hline $\begin{array}{l}\text { ODLC curriculum requires new ways of thinking, as shifting from } \\
\text { teaching to learning }\end{array}$ & 4.13 & .54196 & Agree \\
\hline $\begin{array}{l}\text { ODLC provides innovative development in curriculum, and faculty } \\
\text { is given greater flexibility as they teach their courses. }\end{array}$ & 4.11 & .99394 & Agree \\
\hline
\end{tabular}




\begin{tabular}{|l|r|r|l|}
\hline The content of the course I am teaching is effective & 3.93 & .95224 & Agree \\
\hline $\begin{array}{l}\text { The content of the course I am teaching is connected well to the } \\
\text { rest of the course }\end{array}$ & 4.28 & .80727 & S. Agree \\
\hline I am using in my subject clear images, videos, and use of sound & 4.00 & .81650 & Agree \\
\hline $\begin{array}{l}\text { The blended course I am teaching allows student to understand } \\
\text { what to learn and when to act }\end{array}$ & 4.26 & .97604 & S. Agree \\
\hline Mean average & $\mathbf{4 . 1 4}$ & & Agree \\
\hline
\end{tabular}

\section{Question Four}

To what extent does QOU provide instructors and students with sufficient training for coursework in Blended courses?

The data in Table 6 and 7 exhibits respondents' perception with regard to QOU management role in providing training and support both for instructors and students. The effective role of Al Quds Open University in training both instructors and students was obvious as the mean average registered a value of $(M=4.25)$ that faculty respondents strongly agreed on being provided with necessary and sufficient training by ODLC. However, it was noted that ODLC invested in the training of instructors with regard to software and course design more than the hardware as the mean registered a value $(M=3.96)$ reflected. As for students' attending virtual classes easily, the results were different because the mean was low $(M=2.98)$, This can be due to some technical problems they encounter when logging in the virtual class. However, students strongly agreed that online courses increased the amount of communication between them and their teachers ( $M$ $=4.35$ ).

From the data, researchers conclude the due to QOU philosophy of teaching that does not require students attendance to virtual and/or traditional classes, students attend classes and enter the support unit that QOU provides on their will. From these findings, researchers conclude that the higher education world is changing and opportunities created by technology coupled with the possibilities of distance education are exciting and intimidating at the same time. These changes call for program directors, department chairs, deans, and faculty to demonstrate transformational leadership. Working together to exercise leadership in discussing, planning, and implementing the required changes while at the same time focusing on the central importance of instructors, students and content delivery will provide the best that education has to offer.

Table 6. Respondents' Perception - Staff Training and Support $(N=46)$

\begin{tabular}{|c|c|c|c|c|}
\hline $\begin{array}{l}\text { Section IV: Staff Training and Support } \\
\text { In this e-activities blended learning course; }\end{array}$ & Mean & Std.dev & $\mathbf{N}$ & INTE_VAL \\
\hline $\begin{array}{l}\text { As an instructor, I am trained and supported to adopt this } \\
\text { new teaching paradigm }\end{array}$ & 4.13 & .54196 & .294 & Agree \\
\hline $\begin{array}{l}\text { As an Instructor, I am cognizant of how the details of my } \\
\text { course will be implemented in the new environment }\end{array}$ & 4.39 & .49344 & .243 & S. Agree \\
\hline $\begin{array}{l}\text { ODLC requires me to not only to have knowledge of the } \\
\text { content area, but also to have interpersonal skills to }\end{array}$ & 4.70 & .46522 & .216 & S. Agree \\
\hline
\end{tabular}




\begin{tabular}{|l|r|r|r|l|}
\hline effectively communicate with my students online & & & & \\
\hline $\begin{array}{l}\text { ODLC trained me for adequate technology skill often } \\
\text { needed, such as uploading files, dealing with hardware } \\
\text { and software problems }\end{array}$ & 3.96 & .96509 & .931 & Agree \\
\hline $\begin{array}{l}\text { ODLC trained me to be able to design my courses, making } \\
\text { sure its accessibility to all students }\end{array}$ & 4.26 & .44396 & .197 & S. Agree \\
\hline $\begin{array}{l}\text { ODLC trained me as a frontline contact with students, to } \\
\text { solve the problems as they arise }\end{array}$ & 4.04 & .46935 & .220 & Agree \\
\hline $\begin{array}{l}\text { ODLC has been used to support the development of } \\
\text { higher level thinking skills such as synthesis and problem } \\
\text { solving }\end{array}$ & 4.35 & .56637 & .321 & S. Agree \\
\hline $\begin{array}{l}\text { ODLC technical support site has been used by me to } \\
\text { support more individualized learning programs tailored to } \\
\text { their own individual needs }\end{array}$ & 4.17 & .56977 & .325 & Agree \\
\hline $\begin{array}{l}\text { ODLC trained me to employ educational theories in the } \\
\text { course we teach }\end{array}$ & 4.00 & .91894 & .844 & Agree \\
\hline $\begin{array}{l}\text { ODLC trained me to use a good education practices with } \\
\text { students }\end{array}$ & 4.46 & .58525 & .343 & S. Agree \\
\hline Mean average & 4.25 & & & S. Agree \\
\hline
\end{tabular}

Table 7. Respondents' Perception - Student Training and Support $(\mathrm{N}=46)$

\begin{tabular}{|l|r|r|r|l|}
\hline $\begin{array}{l}\text { Section V: Student training and support } \\
\text { In this e-activities blended learning course; }\end{array}$ & Mean & Std.dev & N & INTE_VAL \\
\hline Students know how to access my subject & 3.96 & .91788 & .843 & Agree \\
\hline Students can get into forum and activities easily & 4.00 & .98883 & .978 & Agree \\
\hline Students can get online quizzes easily & 3.67 & .92025 & .847 & Agree \\
\hline Students attend my virtual classes smoothly & 2.98 & .93069 & .866 & Neutral \\
\hline $\begin{array}{l}\text { I can feel my students are encouraged to take the online } \\
\text { subject }\end{array}$ & 3.80 & .88492 & .783 & Agree \\
\hline $\begin{array}{l}\text { My students are satisfied with the learning strategies used } \\
\text { as in discussion forum }\end{array}$ & 3.89 & .60473 & .366 & Agree \\
\hline $\begin{array}{l}\text { My students are interacting socially with other students } \\
\text { while learning }\end{array}$ & 3.83 & .82474 & .680 & Agree \\
\hline $\begin{array}{l}\text { My students ask me whenever they have problem via } \\
\text { technical support forum }\end{array}$ & 3.74 & .77272 & .597 & Agree \\
\hline $\begin{array}{l}\text { My students enter technical support site ODLC provide } \\
\text { very often }\end{array}$ & 3.67 & .70093 & .491 & Agree \\
\hline $\begin{array}{l}\text { Online courses allow increased amounts of } \\
\text { communication between me and my students. }\end{array}$ & 4.35 & .48154 & .232 & S. Agree \\
\hline $\begin{array}{l}\text { ODLC virtual classes are now acceptable in Palestine } \\
\text { environment }\end{array}$ & 3.96 & .55604 & .309 & Agree \\
\hline Mean average & 3.80 & & & \\
\hline
\end{tabular}

\section{Question Five: The Null Hypotheses}


There are no significant differences in the mean average of respondents' perception $(p<=0.05)$ in QOU management role in leading effective distance learning programs when respondents are grouped according to: Gender, Age, Experience, Program Type, Tutor Status, Computer Skills, Type of Internet Connection, and Tutor Qualification.

Table 8-1. Hypotheses Test

\begin{tabular}{|l|l|l|l|l|l|l|l|l|}
\hline \multirow{2}{*}{ Domain } & \multicolumn{3}{|l|}{ Gender } & \multicolumn{2}{l|}{ Age } & \multicolumn{2}{l|}{ experience } \\
\cline { 2 - 9 } & $\begin{array}{l}\text { Asymp. } \\
\text { Sig. }\end{array}$ & Inter-val & $\begin{array}{l}\text { Asymp } \\
\text { Sig. }\end{array}$ & Inter-val & $\begin{array}{l}\text { Asymp. } \\
\text { Sig. }\end{array}$ & Inter-val & $\begin{array}{l}\text { Asymp. } \\
\text { Sig. }\end{array}$ & Inter-val \\
\hline Vision and Plans & .008 & Rejected & .768 & Accepted & .323 & Accepted & .095 & Accepted \\
\hline Quality Assurance & .002 & Rejected & .318 & Accepted & .102 & Accepted & .746 & Accepted \\
\hline Curriculum & .009 & Rejected & .968 & Accepted & .013 & & .003 & \\
\hline $\begin{array}{l}\text { Staff-Training } \\
\text { Support }\end{array}$ & .699 & Accepted & .074 & Accepted & .723 & Accepted & .327 & Accepted \\
\hline $\begin{array}{l}\text { Student-Training } \\
\text { Support }\end{array}$ & .270 & Accepted & .004 & Rejected & .224 & Accepted & .007 & Rejected \\
\hline All Domain & .005 & Neutral & .139 & Accepted & .508 & Accepted & .041 & Rejected \\
\hline
\end{tabular}

Table 8-2. Hypotheses Test

\begin{tabular}{|l|l|l|l|l|l|l|l|l|}
\hline \multirow{2}{*}{ Domain } & \multicolumn{3}{|l|}{ Tutor Status } & \multicolumn{2}{l|}{ Computer Skills } & \multicolumn{2}{l|}{ Internet connection } & \multicolumn{2}{l|}{ Tutor Qualification } \\
\cline { 2 - 10 } & $\begin{array}{l}\text { Asymp. } \\
\text { Sig. }\end{array}$ & Inter-val & $\begin{array}{l}\text { Asymp } \\
\text { Sig. }\end{array}$ & Inter-val & $\begin{array}{l}\text { Asymp } \\
\text { Sig. }\end{array}$ & Inter-val & $\begin{array}{l}\text { Asymp. } \\
\text { Sig. }\end{array}$ & Inter-val \\
\hline Vision and Plans & .467 & Accepted & .533 & Accepted & .415 & Accepted & .886 & Accepted \\
\hline Quality Assurance & .278 & Accepted & .657 & Accepted & .306 & Accepted & .006 & Rejected \\
\hline Curriculum & .034 & Rejected & .316 & Accepted & .796 & Accepted & .943 & Accepted \\
\hline $\begin{array}{l}\text { Staff-Training } \\
\text { Support }\end{array}$ & .345 & Accepted & .252 & Accepted & .155 & Accepted & .433 & Accepted \\
\hline $\begin{array}{l}\text { Student-Training } \\
\text { Support }\end{array}$ & .676 & Accepted & .023 & Rejected & .688 & Accepted & .053 & Accepted \\
\hline All Domain & .469 & Accepted & .318 & Accepted & .807 & Accepted & .139 & Accepted \\
\hline
\end{tabular}

The hypotheses testing revealed no significant differences in all domains except for domains one and two respectively when respondents were grouped according to their gender. This was in favor of female students since they prefer to stay at home and consequently they have more time to attend and listen to recorded virtual meetings, whereas male students spend time either working or simply being outside the home which does not give them time to attend or listen to the virtual classes. These results are justified with the Palestinian tradition and current situation. Whereas domain 5 (student-training and support) was significant when respondents were grouped according to program type, which was in favor of social science program; while domain 2 and 3 (quality assurance and curriculum) registered a significant differences when respondents were grouped according to instructors status, and this was in favor of full-timers. Finally another significant differences was noted in domain 3 (the Curriculum) and domain 5 (student-training and support) when respondents were grouped according to computer skills, whereas domain 2 (the quality assurance) registered a significant difference when respondent were grouped according to instructors' qualification and this was in favor of the doctoral degree holder.

From these findings, it could be concluded, as to the knowledge of the researchers and the extensive interviews made, that QOU pay high attention to vision and plans, quality assurance, curriculum, and student-training and support more than other domains, as was noted by the test 
results based on the assumption of the participants. This could be as a result of the importance of holding and managing blended learning courses effectively.

\section{Question Six}

What is the obstacles instructors face while teaching blended learning courses, and also the solution to such obstacles as perceived by them?

The third part of the questionnaire consisted of two open questions, the first question required instructors to write down the most five frequent obstacles they face while teaching blended learning courses. They were also required to list them in order - from most to least. In the second question, instructors were asked to write down one solution to each obstacle mentioned in the previous question.

The researchers went through all the 46 questionnaires and started reading what instructors had written down as answers to these questions. It has been found out that seven instructors mentioned five obstacles and five solutions. Twenty instructors mentioned one to two obstacles and solutions. The rest either left the questions unanswered or just wrote one obstacle without mentioning any solutions. However, after summarizing their answers, researchers found that the most frequent five obstacles were:

- Electricity cut down (Brownout) - Gaza Strip only

- Internet connection break out - all Palestinian cities excluding Jerusalem.

- Resistant to change as some Palestinian families still do not believe and allow internet connection at their homes

- Low computer skills, especially instructors with disciplines other than computer science.

- Low incentives to teach blended courses, which do not encourage tutors, taking into consideration that e-learning courses consume more time and efforts and most virtual courses are delivered at evening compared to day-time traditional courses

Some other obstacles were noted in the questionnaires such as: (a) the percentage of blended courses will increase, therefore, e-learning needs compressive training because it takes lots of time, and training are conducted evening time; (b) continuous evaluation for the instructors' training programs, as to instructional design, learning theories, wikis, blog etc.; (c) difficulties in joining virtual classes due to internet crash.

For suggestions for solutions, it was indicated that QOU should have power generators in the educational centers in case of brownout, offer a wireless internet for students and instructors, 
give intensive training in computer skills both for instructors and students, offer incentives for teaching blended courses, and announce examination times in advance.

\section{Conclusions and Recommendations}

Electronic learning programs in Al-Quds Open University and elsewhere in the region play a significant role in the educational system. Therefore, fact-findings in relation to the role of AlQuds Open University of these programs will continue to be very essential and needs to be performed and enhanced periodically. Further research is essential in the areas of program design, program effectiveness, content analysis, the nature of classroom instruction and the impact of all of these on the development of the instructors' professional, personal, and specialist competencies.

Only one study has been done in this line in Palestine as well as in some other Arab countries as to the best knowledge of the researchers. This study was set to investigate the instructors' perceptions on the effectiveness of the QOU role for delivering and handling blended courses. Despite the fact that the participants seem to have acquired satisfactory level competencies, more work is still needed to help them acquire higher level competencies to be able to carry out their duties in an effective and efficient way. Thus, it is very crucial to restructure the electronic learning program taking into account the overall distribution of the courses over the districts of Palestine's main cities, the teaching strategies, and the restriction on student numbers per class, especially in virtual courses with practical nature. In all of these the development of the students' proficiency in electronic learning environment has to be a priority.

This study and other studies in the region (e.g. Al-Mutawa, 1997; Fahmy, et al., 1992; McGee \& Phelan, 2004) show that for the development of instructors and students, certain skills are needed for e-learning as vital for prospective instructors and ODLC. Thus, a paramount attention needs to be directed towards such needs especially at this point in time. Finally, the study shows that the majority of the participants believe that the courses related to the development of tutor's skills and specialist competencies are not sufficient and there is a clear need to look again at the quality and quantity of such courses.

\section{References}

Al-Mutawa, A. (1997). Evaluation of EFL primary school teachers' competencies in Kuwait, Evaluation \& Research in Education, 11(1), 38-52.

Bates, A. W. (2000). Managing technological change: Strategies for college and university leaders. San Francisco: Jossey-Bass.

Bersin, J. (2003). Blended learning: Selecting the right media. How do you decide which media to use? Courseware? PowerPoint? Webinars? Job Aids? Which to use when? Retrieved 10 January 2003 from http://www.bersin.com/tips_techniques/selecting_media.htm 
Collis, B. \& Moonen, J. (2001). Flexible learning in a digital world: Experiences and expectations. London: Kogan Page.

Driscoll, M. (2002). Blended learning: Let's get beyond the hype. IBM Mindspan. Retrieved 10 May 2003 from http://www.elearningmag.com/elearning/article/articleDetail.jsp?id=11755 [10th May, 2003]

Drucker, P. F. (1998). The age of social transformation. In G. R. Hickman (Ed.), Leading organizations: Perspectives for a new era (p. 538-556). Thousand Oaks, CA: Sage.

Fahmy, J. et al. (1992). Planning a TEFL education program: Policies, perspectives and promise. (ERIC Document Reproduction Service No. ED 369 281).

Garrison, D. R. (2003). Blended approaches to teaching and learning: A position paper (Unpublished paper). University of Calgary, Canada.

Garrison, R. \& Vaughan, N. (2007). Blended learning in higher education: Framework, principles, and guidelines. San Francisco, CA: Jossey Bass.

Green, K. C. (1999). When wishes come true: Colleges and the convergence of access, lifelong learning, and technology. Change, March/April. 11-15.

Hall, J. (1995). The revolution in electronic technology and the modern university: The convergence of means. In Y. Evans \& D. Nation (Eds.), Opening education: Policies and practices from open and distance education. New York: Routledge.

Hamayil, M. (2010). Al-Quds Open University experience in blended learning. Retrieved August 15, 2010 from http://tec.alaqsa.edu.ps/conference/?page=confsch

Hodali, I. \& Amro, I. (2004). The implementation of e-learning in Al-Quds Open University. Available at: http://www.etpe.gr/files/proceedings/filessyn/B327-332.pdf

Julian, E. H. \& Boone, C. (2003). Blended learning solutions. Improving the way companies manage intellectual capital. An IDC White paper. Retrieved 11 June 2003 from http://nz.sun.com/training/enterprise/elp/papers/pdf/final_IDC_SES_6_22_01.pdf

Kovel-Jarboe, P. (1997). From the margin to the mainstream: State-level policy and planning for distance education. New Directions for Community Colleges, 99, 23-32.

Lape, D. H. \& Hart, P. K. (1997). Changing the way we teach by changing the college: Leading the way together. New Directions for Community Colleges, 99, 15- 22.

Marsh, J. (2002). How to design effective blended learning (Technical report). Brand-Hall.com.

Matheos, K., Daniel, K., McCalla, G. I. (2005). Dimensions for blended learning technology: Learners' perspectives. Journal of Learning Design, 1(1), 56-76.

Matheos, K., MacDonald, M., McLean, C., Luterbach, B., Baidoun, S., \& Nakashhian, S. (2007). A comprehensive evaluation of Al-Quds Open University. Retrieved 1 July 2009 from http://www.qou.edu/homePage/english/manitobaReport/qouFullReport.pdf

Matheos, K., Rogoza, C., Hamayil, M. (2009) Leapfrogging across generations of open and distance learning at Al-Quds Open University: A Case Study. Available at: http://www.westga.edu/ distance/ojdla/winter124/matheos124.html 
McGee, A. \& G. Phelan, (2004). Needs analysis of pre-service EFL teachers in the United Arab Emirates. Proceedings of the 9th TESOL Arabia Conference (pp. 400-415).

Rovai, A.P. \& Jordan, H.M. (2004). Blended learning and sense of community: A comparative analysis with traditional and fully online graduate courses. International Review of Research in Open and Distance Learning. Retrieved 25 June 2005 from http://www.irrodl.org/ content/v5.2/rovai-jordan.html

Singh, H. (2003). Building effective blended learning programs. Issue of Educational Technology, 43(6), 51-54

Singh, H. \& Reed, C. (2001). Achieving success with blended learning. Washing ton, DC: American Society for Training and Development.

Tichy, N. M. \& Devanna, M. A. (1986). The transformational leader. New York: John Wiley and Sons.

Troha, F.J. (2002) Bulletproof instructional design: Model for blended learning. Journal of United States Distance Learning Association, 15(5). Retrieved 11 November 2003 from http:// www.usdla.org/html/journal/MAY02_Issue/article03.html

UNESCO. (2010). Avicenna page. Retrieved 15 August 2010 from http://pleiad.unesco.org/portal/ index.html?articl=0

Valiathan, P. (2002). Blended learning models. ASTD's Online Magazine. Retrieved 21 May 2003 from: http://www.learningcircuits.com/2002/aug2002/valiathan.html

Correspondence: Dr. Fathallah Ghanem, Lecturer, Al-Quds Open University, Palestine 